\title{
完全適合型高次平面シェル要素を用いた幾何学的非線形解析法

\author{
GEOMETRICALLY NON-LINEAR ANALYSIS METHOD USING \\ COMPLETELY COMPATIBLE PLANER SHELL ELEMENTS \\ WITH HIGHER-ORDER POLYNOMIAL FUNCTIONS
}

\author{
上谷宏二*, 大神勝城** \\ Koji UETANI and Katsuki OHGAMI
}

\begin{abstract}
A new incremental geometrically non-linear analysis method with moving coordinate systems which are continuously moving and rotating during every incremental loading step, is proposed in this paper. This method is adopted for thinwalled structures with planer shells. The geometrical non-linearities treated by the moving coordinate systems and by Von Karman's plate theory, mainly express overall and local buckling deformation, respectively. A rectangular planer shell element on the basis of Von Karman's plate theory, is applied. The efficiency of this method is demonstrated by some example analyses.
\end{abstract}

Keywords : FEM, geometrically non-linear analysis, moving coordinate system, Von Karman's plate theory, overall buckling, local buckling, rectangular planer shell element

有限要素法, 幾何学的非線形解析, 移動座標系, フォン.カルマンの板理論, 全体座屈, 局部座屈, 長方形平面シェル要素

\section{1. 緒言}

著者等は、従来の提案されている板要素よりも少ない自由度数で 精度良く解析できる完全適合型長方形高次平面シェル要素を既に別 報にて提案している1〉。ここでは平板で構成される3 次元の薄肉構 造骨組を対象にして、この高次平面シェル要素の適用と、増分解析 の増分ステップ中でも移動する移動座標系の導入に特徴を持つ幾何 学的非線形解析法を提案する。

幾何学的非線形性を考慮するために、通常の汎用有限要素法プロ グラムやこれまでの論文などで最もよく用いられているのは、Green の歪テンソルに代表される非線形歪テンソルと、増分ステップ中は 固定されているUpdated-Lagrange流の移動座標系を組み合わせたも のである2-7)。この方法では、幾何学的非線形性を表すために、变形 後の要素形状に対して面外扔よび面内変位に関する歪の非線形項を 全て考慮する必要がある。高次要素に適用する場合には、幾何剛性 マトリックスの定式化において非線形項の数が多くなり、計算時間 が増大する。一方、低次要素に適用される場合であっても、構造物 の不安定挙動や崩壊挙動を追跡する場合には、局部座屈が生じる部 分で細かい要素分割が必要となり、計算時間が過大になる。

提案する解析法で使用する要素は、はじめに述へたた 8 節点完全適 合型高次平面シェル要素である注1)。任意の要素境界において撓み
関数はC 1 連続、面内変位関数は C 0 連続に設定されている。ま た、要素境界の有限回転角は、面内あるいは面外を問わず、隅節点 を起点にして要素境界線上に接して埋め込まれた要素境界接線べク トルの回転角成分により厳密に表現される注2)。さらに、要素の歪 と変位の関係式は、撓み勾配の非線形項のみを取り入れたVon Karmanの大撓み理論に基づいて定式化されている。したがって、通 常の歪テンソルに比べて少ない数の歪の非線形項で、要素の撓みに 関する幾何学的非線形性が表される。この定式化の有効性は、周辺 支持された矩形板の曲げ座屈荷重を十分精度よく推定できることに よって既に実証されている1。つまり、板の局部座屈は主として、 Von Karmanの歪の非線形項のみで効率良く表現されることがわかっ ている。しかし、全ての方向の剛体変位を伴う全体座屈をVon Karmanの歪の非線形項のみで表現することはできない。

これまでの幾何学的非線形解析法の研究において、全体座屈モー ドに関係する幾何学的非線形成分が強く現れる挙動の解析に対し て、増分解析の各增分ステップの途中でも常に要素に付随して連続 的に移動する移動座標系を用いることが、極めて有効な方法である ことが知られている8,9)。その理由は、移動座標系を用いれば全体の 変形から剛体変位を分離することで、剛体変位が支配的である全体 座屈の幾何学的非線形性を効率良く表すことができるからである。
* 禁都大学:

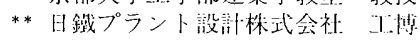

Prof., Dept. of Architecture, Faculty of Engineering, Kyoto University, Dr. Eng. Nittetsu Plant Designing Corporation, Dr. Eng. 
例えば、梁に関しては、移動座標系と撓み勾配の幾何学的非線形項 を組み合わせた事例の報告がある ${ }^{10\rangle}$ 。また、石田等は骨組解析にお いて、要素自身の変形を微小であるとして線形の一般化歪〜変位関 係式を適用した場合でも、移動座標系と提動法を組み合わせて精度 の高い計算結果を得ている ${ }^{11,12)}$ 。さらに、松井等は移動座標系によ る幾何学的非線形性のみを考慮し、曲面要素で構成されたシェルの 座屈問題において、その有効性を確認している ${ }^{13)} 。$

以上の研究成果に鑑みて、今回の解析法では全体座屈を表現する ために移動座標系を導入する。したがって、提案する解析法におけ る幾何剛性マトリックスは、Von Karmanの歪の非線形項成分と移動 座標系による非線形項成分から構成され、それらを組み合わせるこ とで簡潔に、かつ厳密に定式化される。また、移動座標系の下で は、要素境界接線ベクトルの回転角成分と、節点の 3 軸方向並進変 位成分は、剛体変位を取り除いた正味の微小な節点変位成分として 設定される。一方、全体座標系の下では、要素の大きな回転を伴う 場合の構造物の全体変位は、要素境界接線ベクトルの有限回転と節 点の並進移動によって表現される。このように要素境界接線べクト ルの導入に特徵を持つ完全適合型高次平面シェル要素に対して、移 動座標系と要素の撓み勾配の歪の非線形項による幾何学的非線形性 を同時に合わせ持つ解析法をここで提案する。

本論文では、全体座標系と局所移動座標系（今後は局所座標系と 記す）における節点変位成分間の変換則が具体的にかつ厳密に定式 化される。そのうえで、移動座標系を考慮した接線剛性方程式が導 かれる。本解析法の有効性は、基本的な例題を解いて実証される。

\section{2. 移動座標系の導入}

ここでは、構造物の変形に付随して移動する局所座標系の設定方 法や、具体的な座標変換則の定式化について説明する。局所座標系 と全体座標系における節点变位成分は、この座標変換則を介して互 いに関係つけけられる。なお、提案する解析法では、以下の 3 種の座 標系が使用される。（図 1 参照）

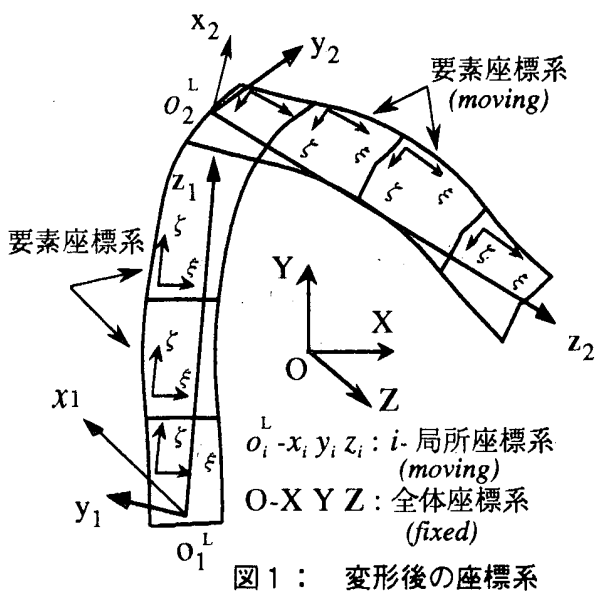

\section{(1)，全体座標系 $(\mathrm{O}-\mathrm{X}$ Y Z $)$}

この座標系は、骨組の変形を記述するための基準固定座標系であ る。要素を形成する節点の座標值や拘束条件等は、この座標系で定 義される。

（2）局所座標系 $\left(\mathrm{O}^{\mathrm{L}}-\mathrm{x}\right.$ y $\left.z\right)$
この座標系は、骨組を構成する部分構造に対して設定される。し たがって、局所座標系は複数存在してよい。この座標系は増分載荷 中も要素に付随して移動する移動座標系である。局所座標系節点変 位成分は、剛体変位成分が取り除かれた正味の変形を表す。

(3) 要素座標系 $\left(O^{E}-\xi \eta \zeta\right)$

この座標系は、板要素毎に設けられる座標系であり、要素の応力 や歪計算に用いられる。局所座標系と要素座標系の位置関係は、骨 組の变形前後で一定である。したがって、要素座標系変位成分は局 所座標系変位成分と同様に正味の変形を表す。

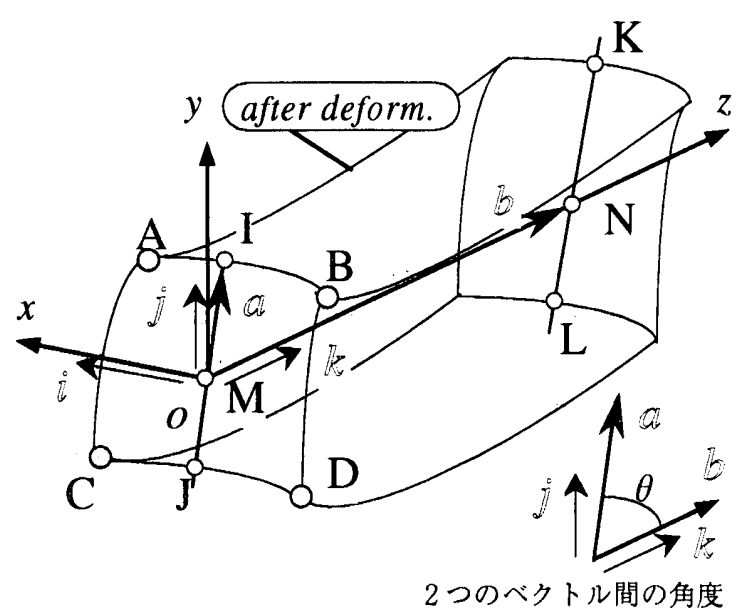

図 2： 局所座標系の定義の例

\section{2 - 1 . 局所座標系の設定方法}

ここでは、薄肉構造骨組の一例として図 2 に示すような部材を取 り出して、局所座標系を設定する方法が具体的に説明される。局所 座標系は、部材の前後端の断面の上下辺の中点である 4 個の代表節 点 $\mathrm{I}, \mathrm{J}, \mathrm{K}, \mathrm{L}$ を基準に決定される。まず、点 $\mathrm{I} ， \mathrm{~J}$ の中点 $\mathrm{M}$ と点 $\mathrm{K} ， \mathrm{~L}$ の中点 $\mathrm{N}$ を結ぶベクトル $\mathrm{MN}$ を $\mathrm{Z}$ 軸にして、点 $\mathrm{M}$ を局所座標 系の原点にする。さらに、Z軸とベクトルM I を含む平面内で、点 I のある側に $\mathrm{y}$ 軸が定義される。最後に $\mathrm{x}$ 軸は、他の 2 軸を参照し て右手ねじ系の規則に従って自動的に決定される。

図 2 の局所座標系の基底ベクトルは、以下のように求められる。

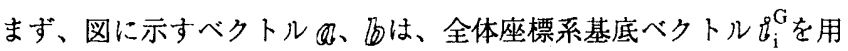
いて以下のように表わされる。

$$
\begin{gathered}
\overrightarrow{\mathrm{MI}} \equiv \mathscr{G}=a_{1} \mathfrak{b}_{0}+a_{2} \mathfrak{J}_{0}+a_{3} \mathbb{B}_{0} \\
\overrightarrow{\mathrm{MN}} \equiv \emptyset=b_{1} \mathfrak{b}_{0}+b_{2} \mathfrak{J}_{0}+b_{3} \vec{k}_{0} \\
\text { ただし、 }\left\{b_{\mathrm{i}}^{\mathrm{G}}\right\}=\left\{\mathfrak{b}_{0} \mathfrak{J}_{0} \mathbb{b}_{0}\right\}^{\prime}
\end{gathered}
$$

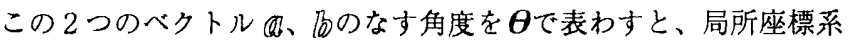
基底べクトルる゙、以下のように表わされる。

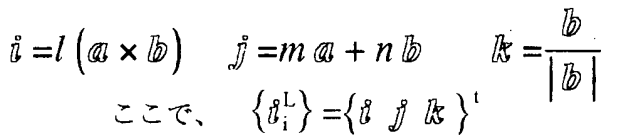

$$
\begin{aligned}
& l=\frac{1}{|\operatorname{cob}||(b)| \sin \theta} \quad m=\frac{1}{|\operatorname{cob}| \sin \theta} \quad n=-\frac{1}{|b| \tan \theta}
\end{aligned}
$$


（2）式に（1）式を代入して、2つの座標系の基底べクル間の関 係は以下のように求められる。

$\left[\begin{array}{l}\downarrow \\ d \\ d k\end{array}\right]=\left[\begin{array}{ccc}l\left(a_{2} b_{3}-a_{3} b_{2}\right) & l\left(a_{3} b_{1}-a_{1} b_{3}\right) & l\left(a_{1} b_{2}-a_{2} b_{1}\right) \\ m a_{1}+n b_{1} & m a_{2}+n b_{2} & m a_{3}+n b_{3} \\ \frac{b_{1}}{|b|} & \frac{b_{2}}{|b|} & \frac{b_{3}}{|b|}\end{array}\right]\left[\begin{array}{l}b_{0} \\ \jmath_{0} \\ b_{0}\end{array}\right]$

一方、ベクトルのとゆの各成分は、代表節点の座標值 $X_{\mathrm{q}}^{\mathrm{r}}$ を用いて 以下のように表される。

$$
\begin{aligned}
& a_{\mathrm{m}}=A_{\mathrm{mq}} X_{\mathrm{q}}^{\mathrm{r}} \quad b_{\mathrm{m}}=B_{\mathrm{mq}} X_{\mathrm{q}}^{\mathrm{r}}(\mathrm{m}=1,3 \quad \mathrm{q}=1,12) \\
& \text { ここで、 }
\end{aligned}
$$

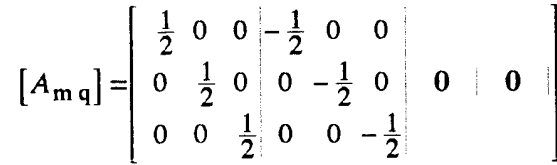

$$
\begin{aligned}
& {\left[B_{\mathrm{m} \mathrm{q}}\right]=\left[\begin{array}{ccc:ccc:ccc:ccc}
-\frac{1}{2} & 0 & 0 & -\frac{1}{2} & 0 & 0 & \frac{1}{2} & 0 & 0 & \frac{1}{2} & 0 & 0 \\
0 & -\frac{1}{2} & 0 & 0 & -\frac{1}{2} & 0 & 0 & \frac{1}{2} & 0 & 0 & \frac{1}{2} & 0 \\
0 & 0 & -\frac{1}{2} & 0 & 0 & -\frac{1}{2} & 0 & 0 & \frac{1}{2} & 0 & 0 & \frac{1}{2}
\end{array}\right]}
\end{aligned}
$$

同様に、局所座標系の原点の並進変位速度成分 $\dot{U}_{0 \mathrm{i}}$ は、代表節点 の変位速度成分 $\dot{U}_{\mathrm{q}}^{\mathrm{r}}$ を用いて以下のように表せる。

$$
\begin{aligned}
& \dot{U}_{0 \mathrm{i}}=C_{\mathrm{iq}} \dot{U}_{\mathrm{q}}^{\mathrm{r}} \quad(\mathrm{i}=1,3 \quad \mathrm{q}=1,12)
\end{aligned}
$$

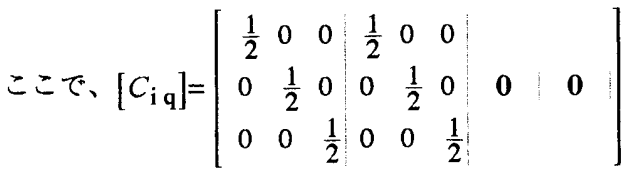

\section{2-2．座標変換行列の誘道}

（1）基底ベクトルと要秦境界接線ベクトル間の関係式

局所座標系の基底ベクトル $\emptyset_{\mathrm{i}}^{\mathrm{L}}$, 全体座標系の基底ベクトル $\mathfrak{l}_{\mathrm{i}}^{\mathrm{G}}$ と按 線ベクトル 6 の 3 者は、図 3 に示すように次式で関係づけられる。

$$
l_{\mathrm{i}}^{\mathrm{T}}=\Omega_{\mathrm{ij}} l_{\mathrm{j}}^{G} \quad \mathscr{G}=R_{\mathrm{j}}^{\mathrm{L}} \ell_{\mathrm{j}}^{\mathrm{I}} \quad Q=R_{\mathrm{j}}^{G} q_{\mathrm{j}}^{\mathrm{G}}
$$

ただし、 $\Omega_{\mathrm{ij}}$ は、全体座標系軸回りの回転角成分 $\bar{\alpha}_{\mathrm{j}}$, 他の俰数は接 線ベクトルの回転角 $\Theta_{\mathrm{i}}, \theta_{\mathrm{i}}$ を用いて次のように表わされる。

$\left\{\Omega_{\mathrm{ij}}\right\}=\left[\begin{array}{cc}\sin \bar{\alpha} \sin \bar{\beta} \sin \bar{\gamma}+\cos \bar{\beta} \cos \bar{\gamma}, & \cos \bar{\alpha} \sin \bar{\gamma}, \sin \bar{\alpha} \cos \bar{\beta} \sin \bar{\gamma}-\sin \bar{\beta} \cos \bar{\gamma} \\ \sin \bar{\alpha} \sin \bar{\beta} \cos \bar{\gamma}-\cos \bar{\beta} \sin \bar{\gamma}, & \cos \bar{\alpha} \cos \bar{\gamma}, \sin \bar{\alpha} \cos \bar{\beta} \cos \bar{\gamma}+\sin \bar{\beta} \sin \bar{\gamma} \\ \cos \bar{\alpha} \sin \bar{\beta} & -\sin \bar{\alpha},\end{array}\right]$

$\left\{R_{\mathbf{j}}^{G}\right\}=\left[\begin{array}{lll}\cos \Theta \cos \Phi & \sin \Theta \cos \Phi \quad \sin \Phi\end{array} \mid\right.$

$\left\{R_{\mathbf{j}}^{\mathrm{L}}\right\}=\left[\begin{array}{lll}\cos \theta \cos \varphi & \sin \theta \cos \varphi \quad \sin \varphi\end{array} \mid\right.$

ここで、 $\bar{\alpha}_{\mathbf{j}}$ の 3 成分 $\bar{\alpha}, \bar{\beta}, \bar{\gamma}$ は、全体座標系を 3 軸回りに回転させ
て、局所座標系に完全に一致させる場合に必要な有限回転角であ る。すなわち、全体座標系は、まず第 3 軸回りに $\gamma$ 回転し、次に初 期の全体座標系の第 1 軸回りに $\bar{\alpha}$ 回転した後、初期の全体座標系の 第 2 軸回りに佃転することで、局所座標系に重ねることができ る。ところで、この種の座標変換の記述には、他にオイラー角を用 いる方法がある。それに対して、著者らは全体座標系軸回りの回転 角成分との対応を見るために、前述の $\bar{\alpha}, \beta 、 \bar{\gamma}$ を使用してオイラー 角を使用した場合と異なる記述の座標変換を構築している。

一方、4 隅の節点位圈で要素境界に接して埋め込まれた要素境界 接線ベクトルは、図 4 に示すように、まず第 1 軸を起点にして第 3 軸回りに有限回転 $(\Theta$ or $\theta)$ し、さらにその位固から第 3 軸に向かっ て有限回転 $(\Phi$ or $\varphi)$ することで、3 次元空間を回転移動する。

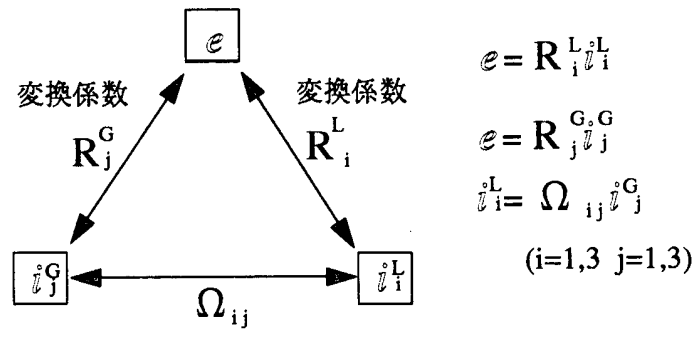

変換マトリックス

図 3 : 座標系の基底ベクトルと境界接線ベクトルの関係
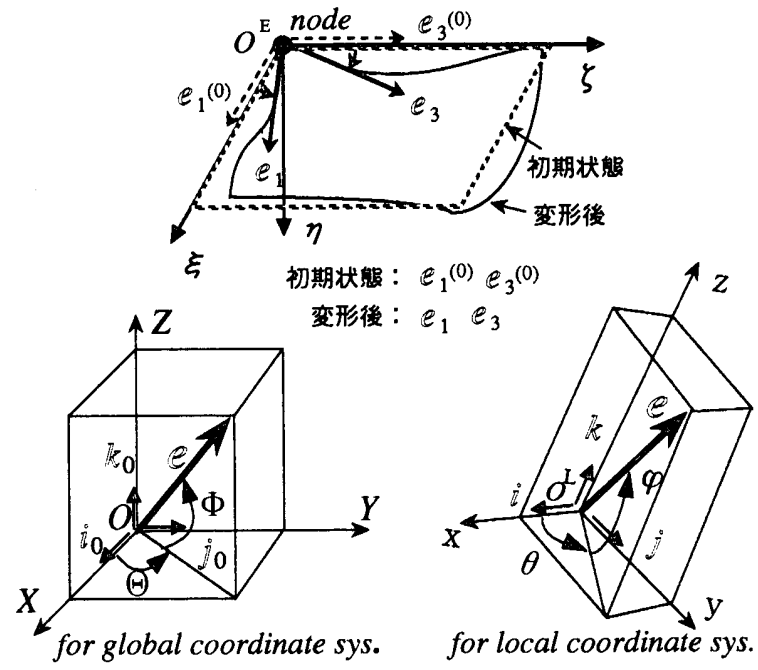

$\Theta_{\theta}^{\Theta} \underset{\varphi}{\Phi}$ : spherical coordinate system

図 4：要素境界接線ベクトルの回転角成分

（2）局所座標系基底ベクトル 点と 再者は以下のように直交条件を満足する。

$$
\begin{aligned}
& { }_{b} \cdot a_{b}=\Omega_{1 \mathrm{~m}} \quad a_{\mathrm{m}}=0 \quad i b \cdot b=\Omega_{1 \mathrm{~m}} b_{\mathrm{m}}=0 \\
& \text { j] } \cdot \text { b }=\Omega_{2 \mathrm{~m}} b_{\mathrm{m}}=0 \quad(m=1,3)
\end{aligned}
$$

（8）式を速度式で表わすと以下のようになる。

$$
\begin{gathered}
\frac{\partial \Omega_{1 \mathrm{~m}}}{\partial \bar{\alpha}_{\mathrm{j}}} a_{\mathrm{m}} \dot{\bar{\alpha}}_{\mathrm{j}}+\Omega_{1 \mathrm{~m}} \dot{a}_{\mathrm{m}}=0 \quad \frac{\partial \Omega_{1 \mathrm{~m}}}{\partial \bar{\alpha}_{\mathrm{j}}} b_{\mathrm{m}} \dot{\bar{\alpha}}_{\mathrm{j}}+\Omega_{1 \mathrm{~m}} \dot{b}_{\mathrm{m}}=0 \\
\frac{\partial \Omega_{2 \mathrm{~m}}}{\partial \bar{\alpha}_{\mathrm{j}}} b_{\mathrm{m}} \dot{\bar{\alpha}}_{\mathrm{j}}+\Omega_{2 \mathrm{~m}} \dot{b}_{\mathrm{m}}=0
\end{gathered}
$$


（9）式に（4）式を代入して次式を得る。

$$
\begin{aligned}
& \frac{\partial \Omega_{1 \mathrm{~m}}}{\partial \bar{\alpha}_{\mathrm{j}}} A_{\mathrm{mq}} X_{\mathrm{q}}^{\mathrm{r}} \dot{\bar{\alpha}}_{\mathrm{j}}+\Omega_{1_{\mathrm{m}}} A_{\mathrm{mq}} \dot{U}_{\mathrm{q}}^{\mathrm{r}}=0 \\
& \frac{\partial \Omega_{1 \mathrm{~m}}}{\partial \bar{\alpha}_{\mathrm{j}}} B_{\mathrm{mq}} X_{\mathrm{q}}^{\mathrm{r}} \dot{\bar{\alpha}}_{\mathrm{j}}+\Omega_{1 \mathrm{~m}} B_{\mathrm{mq}} \dot{U}_{\mathrm{q}}^{\mathrm{r}}=0 \\
& \frac{\partial \Omega_{2 \mathrm{~m}}}{\partial \bar{\alpha}_{\mathrm{j}}} B_{\mathrm{mq}} X_{\mathrm{q}}^{\mathrm{r}} \dot{\bar{\alpha}}_{\mathrm{j}}+\Omega_{2 \mathrm{~m}} B_{\mathrm{mq}} \dot{U}_{\mathrm{q}}^{\mathrm{r}}=0
\end{aligned}
$$

（10）式は、整理して以下のように表わしておく。

$$
G_{\mathrm{i},} \dot{\bar{\alpha}}_{\mathrm{j}}+H_{\mathrm{iq}} \dot{U}_{\mathrm{q}}^{\mathrm{r}}=0(\mathrm{i}=1,3 \mathrm{j}=1,3 \mathrm{q}=1,12)
$$

ただし、 $G_{1 \mathrm{j}}=\frac{\partial \Omega_{1 \mathrm{~m}}}{\partial \bar{\alpha}_{\mathrm{j}}} A_{\mathrm{mq}} X_{\mathrm{q}}^{\mathrm{r}} \quad G_{2 \mathrm{j}}=\frac{\partial \Omega_{1 \mathrm{~m}}}{\partial \bar{\alpha}_{\mathrm{j}}} B_{\mathrm{mq}} X_{\mathrm{q}}^{\mathrm{r}}$

$$
\begin{aligned}
& G_{3 \mathrm{j}}=\frac{\partial \Omega_{2 \mathrm{~m}}}{\partial \bar{\alpha}_{\mathrm{i}}} B_{\mathrm{mq}} X_{\mathrm{q}}^{\mathrm{r}} \quad H_{1 \mathrm{q}}=\Omega_{1 \mathrm{~m}} A_{\mathrm{mq}} \\
& H_{2 \mathrm{q}}=\Omega_{1 \mathrm{~m}} B_{\mathrm{mq}} \quad H_{3 \mathrm{q}}=\Omega_{2 \mathrm{~m}} B_{\mathrm{mq}}
\end{aligned}
$$

したがって、（11）式から、次の関係式を得る。

$$
\dot{\bar{\alpha}}_{\mathrm{j}}=-G_{\mathrm{i} \mathrm{i}}^{-1} H_{\mathrm{iq}} \dot{U}_{\mathrm{q}}^{\mathrm{r}}
$$

（3）節点の並進変位成分に関する変換則

図 5 に任意の点Aを局所座標系と全体座標系の位置ベクトルを用い て示す。ベクトル和を考えると次の式が成り立つ。

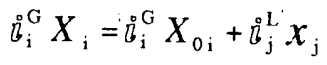

（6）式の第1式を代入して整理すると以下のようになる。

$$
X_{\mathrm{i}}=X_{0 \mathrm{i}}+\Omega_{\mathrm{ji}} \cdot x_{\mathrm{j}}
$$

また、（14）式を時間微分すると次の変位速度式が成り立つ。

$$
\dot{U}_{\mathrm{i}}=\dot{U}_{0 \mathrm{i}}+\frac{\partial \Omega_{\mathrm{mi}}}{\partial \bar{\alpha}_{l}} x_{\mathrm{m}} \dot{\bar{\alpha}}_{l}+\Omega_{\mathrm{ji}} \dot{u}_{\mathrm{j}}
$$

右辺の第 1 項に（5）式、第 2 項に（12）式を代入して整理すると次 式が導かれる。

$$
\begin{gathered}
\dot{U}_{\mathrm{j}}=\Omega_{\mathrm{ij}}{ }^{-1} \dot{U}_{\mathrm{i}}-\Omega_{\mathrm{ij}}{ }^{-1} C_{\mathrm{iq}} \dot{U}_{\mathrm{q}}^{\mathrm{r}}+\Omega_{\mathrm{ij}}{ }^{-1} \frac{\partial \Omega_{\mathrm{mi}}}{\partial \bar{\alpha}_{l}} x_{\mathrm{m}} G_{l \mathrm{n}}{ }^{-1} H_{\mathrm{nq}} \dot{U}_{\mathrm{q}}^{\mathrm{r}} \\
=\Omega_{\mathrm{ij}}{ }^{-1} \dot{U}_{\mathrm{i}}+\Omega_{\mathrm{ij}}{ }^{-1}\left(\frac{\partial \Omega_{\mathrm{mi}}}{\partial \bar{\alpha}_{l}} x_{\mathrm{m}} G_{l \mathrm{n}}{ }^{-1} H_{\mathrm{nq}}-C_{\mathrm{iq}}\right) \dot{U}_{\mathrm{q}}^{\mathrm{r}} \\
(\mathrm{i}=13 \mathrm{j}=1,3 \mathrm{k}=1,3 \quad l=1,3 \mathrm{~m}=1,3 \mathrm{n}=1,3 \mathrm{q}=1,12)
\end{gathered}
$$

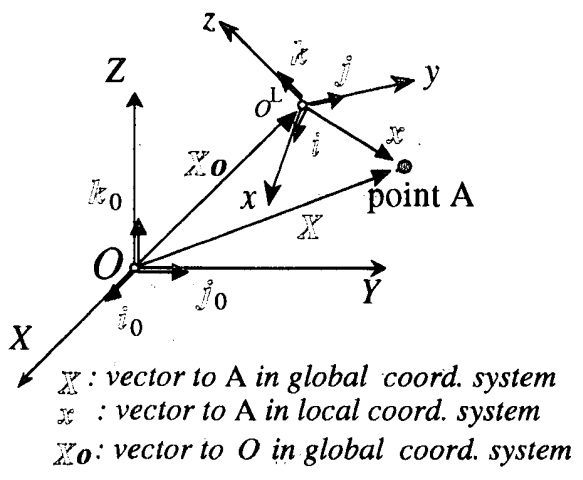

図 5： 全体座標系と局所座標系の位贯ベクトル

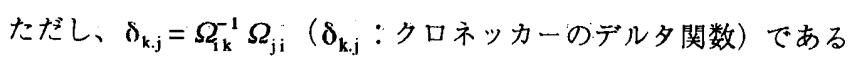
と定義する。

\section{（4）要秦境界接線ベクトルの回転角成分に関する変換則}

要素境界の回転は、接線ベクトルの 2 個の回転角成分を用いて表 現される。（6）式より、次の関係式が得られる。

$$
\mathscr{E}=R_{\mathrm{k}}^{\mathrm{L}}{ }_{\mathrm{b}}^{\mathrm{L}}=R_{\mathrm{k}}^{\mathrm{L}} \Omega_{\mathrm{ki}} \dot{b}_{\mathrm{i}}^{\mathrm{G}}=R_{\mathrm{i}}^{\mathrm{G}} \stackrel{\circ}{\mathrm{b}}_{\mathrm{i}}^{\mathrm{G}}
$$

したがって、次式が導かれる。

$$
R_{i}^{\mathrm{G}}=\Omega_{\mathrm{ki}} R_{\mathrm{k}}^{\mathrm{L}}
$$

（18）式の右辺を左辺に移項して、速度表示することで(19)式が導か れる。

$$
D_{\mathrm{i} \mathrm{K}} \dot{\Theta}_{\mathrm{K}}+E_{\mathrm{iJ}} \dot{\theta}_{\mathrm{J}}+F_{\mathrm{i} l} \dot{\bar{\alpha}}_{l}=0 \quad(\mathrm{i}=k=l=1,3 \quad \mathrm{~K}=\mathrm{J}=1,2)
$$

ただし、 $D_{\mathrm{i} \mathrm{K}}=\frac{\partial R_{\mathrm{i}}^{\mathrm{G}}}{\partial \Theta_{\mathrm{K}}}, E_{\mathrm{i}, \mathrm{l}}=-\Omega_{k \mathrm{i}} \frac{\partial R_{k}^{\mathrm{L}}}{\partial \theta_{\mathrm{J}}}, F_{\mathrm{i} l}=-\frac{\partial \Omega_{k \mathrm{i}}}{\partial \bar{\alpha}_{l}} R_{k}^{\mathrm{L}}$

ここで、（19）式は 3 行の方程式を構成するが、大文字の添字で表 した要素境界接線ベクトルの 2 個の回転角成分を求めるために、そ の中から 2 行を選択する必要がある。そのうえで、左辺の第 3 式に

（12）式を代入して整理すると（20）式が導かれる。

$$
\begin{aligned}
\dot{\theta}_{\mathrm{J}}= & -E_{\mathrm{JI}}^{-1} D_{\mathrm{lK}} \dot{\Theta}_{\mathrm{K}}-E_{\mathrm{JI}}^{-1} F_{\mathrm{I} l} \dot{\bar{\alpha}}_{l} \\
= & -E_{\mathrm{J} \mathrm{I}}^{-1} D_{1 \mathrm{~K}} \dot{\Theta}_{\mathrm{K}}+E_{\mathrm{J} J}^{-1} F_{\mathrm{l} l} G_{l \mathrm{n}}^{-1} H_{\mathrm{nq}} \dot{U}_{\mathrm{q}}^{\mathrm{r}} \\
& (\mathrm{I}=1,2 \mathrm{~J}=1,2 \mathrm{~K}=1,2 \quad l=1,3 \quad \mathrm{n}=1,3 \quad \mathrm{q}=1,12)
\end{aligned}
$$

なお、 2 行選択の理由は、<1>要素境界接線ベクトルは図 4 に示す ように 2 個の回転角成分で定義されるので 2 行の式で関係づけられ ること、<2>例えば、接線べクトルが直交座標系の 3 軸の内、 $\mathrm{XY}, \mathrm{YZ}$ およ゙ZX平面にある場合は 2 つの基底べクトルのみで表わさ れるため、それに対応する2行の方程式を選択することになるため である。また、任意の接線ベクトルが 3 つの基底べクトルを用いて 定義される場合でも、それぞれ 2 行の式の組み合わせにおいて、 (20)式の右辺第 1 項の $2 \times 2$ の小行列の行列式の值（Determinant)の 絶対値が最大になる場合を採用すればよいと考えられる。

(5) 座標変換行列

（16）式と（20）式によって、並進変位 3 成分と回転角 2 成分の局 所座標系と全体座標系節点変位成分、および 4 個の代表節点の並進

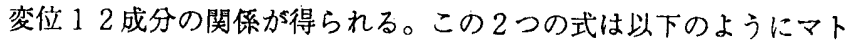
リックスの形に表わすことができる。

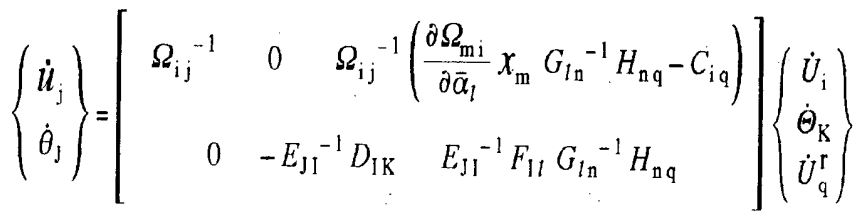

（21）式を全ての節点に対して導けば、全体座標系変位速度 $\dot{\Delta}_{n}^{G}$ と局 所座標系変位速度 $\dot{\Delta}_{\mathbf{m}}^{\mathrm{L}}$ は、移動座標変換マトリックス $T_{\mathrm{m} n}$ を用いて 以下のように関係づけられる。 
$\dot{\Delta}_{\mathrm{m}}^{\mathrm{L}}=T_{\mathrm{mn}} \cdot \dot{\Delta}_{\mathrm{n}}^{\mathrm{G}} \quad(\mathrm{m}, \mathrm{n}=$ total degrees of freedom $)$

\section{3. 座標変換則を考慮した接袙剛性方程式}

ここでは、板要素に関する接線剛性方程式を、(23)式に示す全体 座標系における仮想仕事式を用いて導出する。

$$
\int_{V} \sigma_{\mathrm{k}} \delta \varepsilon_{\mathrm{k}} d v=P_{\mathrm{p}} \delta \Delta_{\mathrm{p}}^{\mathrm{G}}
$$

左辺の仮想歪は、(24)式を用いて(25)式で表される。ただし、 $\dot{\alpha}_{\mathrm{i}}$ は一 般化変位速度である。

$$
\begin{gathered}
\dot{\varepsilon}_{\mathrm{k}}=B_{\mathrm{ki}} \dot{\alpha}_{\mathrm{i}} \quad \dot{\alpha}_{\mathrm{i}}=L_{\mathrm{im}} \dot{\Delta}_{\mathrm{m}}^{\mathrm{L}}=L_{\mathrm{im}} T_{\mathrm{mp}} \dot{\Delta}_{\mathrm{p}}^{\mathrm{G}} \\
\delta \varepsilon_{\mathrm{k}}=B_{\mathrm{ki}} \delta \alpha_{\mathrm{i}}=B_{\mathrm{ki}} L_{\mathrm{im}} T_{\mathrm{mp}} \delta \Delta_{\mathrm{p}}^{\mathrm{G}}
\end{gathered}
$$

(23)式に(25)式を代入して、全体座標系における力の釣り合い式が次 式で表される。

$$
L_{\mathrm{im}} T_{\mathrm{mp}} \int_{V} \sigma_{\mathrm{k}} B_{\mathrm{ki}} d v=P_{\mathrm{p}}
$$

(26)式の両辺を経路パラメータ tで微分すると、以下の速度関係式 が得られる。

$L_{\mathrm{im}} \dot{T}_{\mathrm{mp}} \int_{V} \sigma_{\mathrm{k}} B_{\mathrm{ki}} d v+L_{\mathrm{im}} T_{\mathrm{mp}} \int_{V}\left(\dot{\sigma}_{\mathrm{k}} B_{\mathrm{ki}}+\sigma_{\mathrm{k}} \dot{B}_{\mathrm{ki}}\right) d v=\dot{P}_{\mathrm{p}}$

$T_{\mathrm{mp}}$ は局所座標系節点変位成分 $\Delta_{\mathrm{m}}^{\mathrm{L}}$ と全体座標系の節点変位成分 $\Delta_{\mathrm{n}}^{G}$ および回転角六,の関数であり、かつ 3 者は従属関係にあるので(27) 式の左辺の第 1 項は、(28)式を用いて(29)式のように変形される。た だし、 $p_{\mathrm{m}}$ は局所座墂系の等価節点力を表す。

$$
\begin{gathered}
\dot{T}_{\mathrm{mp}}=\left[\frac{\partial T_{\mathrm{mp}}}{\partial \Delta_{\mathrm{q}}^{\mathrm{G}}}+\frac{\partial T_{\mathrm{mp}}}{\partial \Delta_{\mathrm{n}}^{\mathrm{L}}} \frac{\partial \Delta_{\mathrm{n}}^{\mathrm{L}}}{\partial \Delta_{\mathrm{q}}^{\mathrm{G}}}+\frac{\partial T_{\mathrm{mp}}}{\partial \bar{\alpha}_{l}} \frac{\partial \bar{\alpha}_{l}}{\partial \Delta_{\mathrm{q}}^{\mathrm{G}}}\right] \dot{\Delta}_{\mathrm{q}}^{\mathrm{G}}=\frac{\partial T_{\mathrm{mp}}}{\partial \bar{\Delta}_{\mathrm{q}}^{\mathrm{G}}} \dot{\Delta}_{\mathrm{q}}^{\mathrm{G}} \\
p_{\mathrm{m}}=L_{\mathrm{im}} \int_{V}^{\sigma_{\mathrm{k}} B_{\mathrm{ki}} d v} \\
L_{\mathrm{im}} \dot{T}_{\mathrm{mp}} \int_{V} \sigma_{\mathrm{k}} B_{\mathrm{ki}} d v=p_{\mathrm{m}} \frac{\partial T_{\mathrm{mp}}}{\partial \hat{\Delta}_{\mathrm{q}}^{\mathrm{G}}} \dot{\Delta}_{\mathrm{q}}^{\mathrm{G}}
\end{gathered}
$$

一方、（27）式の右辺の第 2 項は以下のように変形される。

$$
\begin{aligned}
& L_{\mathrm{im}} T_{\mathrm{mp}} \int_{V}\left(\dot{\sigma}_{\mathrm{k}} B_{\mathrm{ki}}+\sigma_{\mathrm{k}} \dot{B}_{\mathrm{ki}}\right) d v \\
= & L_{\mathrm{im}} T_{\mathrm{mp}} \int_{V}\left(B_{\mathrm{ki}} D_{\mathrm{k} l} B_{l \mathrm{j}}+\sigma_{\mathrm{k}} \frac{\partial B_{\mathrm{ki}}}{\partial \alpha_{\mathrm{j}}}\right) d v \dot{\alpha}_{\mathrm{j}} \\
= & L_{\mathrm{im}} T_{\mathrm{mp}} k_{\mathrm{ij}}^{\alpha} \dot{\alpha}_{\mathrm{j}}=L_{\mathrm{im}} T_{\mathrm{mp}} k_{\mathrm{ij}}^{\alpha} L_{\mathrm{jn}} \dot{\Delta}_{\mathrm{n}}^{\mathrm{L}}=T_{\mathrm{mp}} k_{\mathrm{m} \mathrm{n}} T_{\mathrm{nq}} \dot{\Delta}_{\mathrm{q}}^{\mathrm{G}}
\end{aligned}
$$

$$
\begin{gathered}
\dot{\sigma}_{\mathrm{k}}=D_{\mathrm{k} l} \dot{\varepsilon}_{l}=D_{\mathrm{k} l} B_{l \mathrm{j}} \dot{\alpha}_{\mathrm{j}} \quad \dot{B}_{\mathrm{ki}}=\frac{\partial B_{\mathrm{ki}}}{\partial \alpha_{\mathrm{j}}} \dot{\alpha}_{\mathrm{j}} \\
k_{\mathrm{ij}}^{\alpha}=\int_{V}\left(B_{\mathrm{ki}} D_{\mathrm{k} l} B_{l \mathrm{j}}+\sigma_{\mathrm{k}} \frac{\partial B_{\mathrm{ki}}}{\partial \alpha_{\mathrm{j}}}\right) d v \\
k_{\mathrm{mn}}=L_{\mathrm{im}} k_{\mathrm{ij}}^{\alpha} L_{\mathrm{jn}} \quad \dot{\Delta}_{\mathrm{n}}^{\mathrm{L}}=T_{\mathrm{nq}} \dot{\Delta}_{\mathrm{q}}^{\mathrm{G}}
\end{gathered}
$$

（29）式と（30）式を（27）式に代入して、全体座標系における接 線剛性方程式が以下のように導かれる。

$$
\begin{gathered}
K_{\mathrm{pq}}^{*} \dot{\Delta}_{\mathrm{q}}^{\mathrm{G}}=\dot{P}_{\mathrm{p}} \quad \text { ただし、 } K_{\mathrm{pq}}^{*}=p_{\mathrm{m}} \frac{\partial T_{\mathrm{mp}}}{\partial \widehat{\Lambda}_{\mathrm{q}}^{\mathrm{G}}}+T_{\mathrm{mp}} k_{\mathrm{m} \mathrm{n}} T_{\mathrm{nq}} \\
(\mathrm{k}, l=1,3 \text { other index }=1,40)
\end{gathered}
$$

(31)式の剛性マトリックスは、第 1 項に移動座標系による幾何学的 非線形成分を含んでいる。また、(30)式の一般化剛性マトリックス $k_{\mathrm{i} j}^{\alpha}$ の第 2 項目の成分は、Von Karman の大挜み理論に基づく幾何学 的非線形成分であり、(31)式の第 2 項を構成する。したがって、(31) 式の剛性マトリックスの中には、これら 2 種類の幾何学的非線形成 分が、個別に含まれているのがわかる。

\section{4.要秦境界接線ベクトルの回転角成分に対応する等価節点力}

本解析法では、任意の要素境界における適合条件を過不足無く满 足させるために要素境界接線ベクトルを導入している。それぞれの 要素境界接線ベクトルの回転移動を表現する2 個の回転角成分は、 個別の節点変位成分として取り扱われる。また、その回転角成分 は、図 4 で示したように球座標系での有限回転角として表わされ る。このことは、任意の節点の回転変位を全体座標系での 3 軸回り の回転角成分で表現する通常の有限要素法に比べて、節点の回転角 成分の数拄3) と回転角の表現方法が異なっている。したがって、節 点の回転角成分に対㐫して球座標系の等価節点モーメント $M_{j}^{\boldsymbol{\theta}}$ と全 体座標系の 3 軸回りの等価節点モーメント $\boldsymbol{M}_{i}$ の間の関係を明確にし て扔くことが必要である。ここでは 1 本の要素境界接線べクトルを 例にとり、西者の関係式が以下の仮想仕事式を用いて導かれる。

$$
\begin{aligned}
\text { 仮想仕事 }: \delta \mathrm{W}_{\mathrm{EX}}=M_{i} \cdot \delta \hat{\Theta}_{i}=M_{j}^{\Theta} \delta \Theta_{j} \\
(i=1,2 \quad j=1,2)
\end{aligned}
$$

図 $6 に$ に、任意の角度に要素境界接線ベクトルが有限回転した位直 から、さらに2つの方法で微小に仮想回転したとさの模式図を示 す。このとき方法(a)の仮想回転角 $\delta \hat{\Theta}_{i}$ は、有限回転角と同じ方向の 仮想回転角 $\delta \Theta_{\mathrm{j}}$ でなく、全体座標系の軸回りの仮想回転角である。一 般的には、 $\delta \hat{\Theta}_{\mathrm{i}}$ と $\delta \Theta_{\mathrm{j}}$ は一致しないが、(33)式で示すように移動後の 2 つのベクトルは共に等しいと仮定することにより、而者を関係づ けることができる。具体的には、G゙は(6)の第 3 式を用いて、微小 仮想回転後のベクトルを求めることで(34)式の第 2 式で表わされ る。また、乎・は以下に説明する手順で幾何学的に決定される。ま ず、ベクトルタの先端の点AをXY平面、YZ平面へ投影してそれぞれ 点A1,A2とする。次にベクトルGと辺OA1を含む面をZ軸回りに $\delta \hat{\Theta}_{7}$

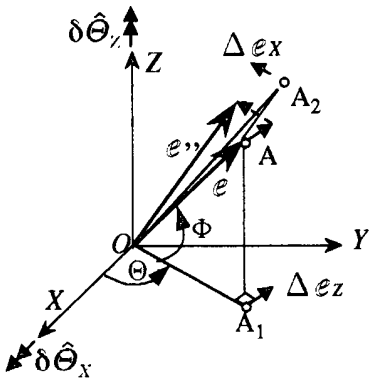

(a) 有限回転後の位置を 基準にして、全体座標系軸 回りに仮想回転させた場合

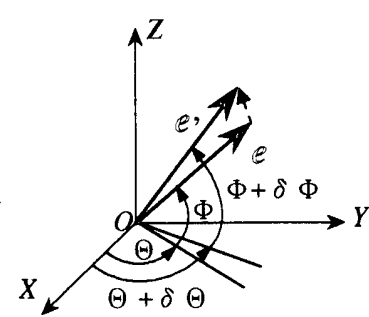

(b) 有限回転角の方向に 仮想回転させた場合
図 6：仮想回転後の要秦境界接線ベクトル 
だけ回転後、ベクトルGと辺OA2を含む面をX軸回りに $\hat{\Theta}_{X}$ だけ回転 させる。このとき、冓は（34）の第 1 式で求められる。

$$
\mathcal{C}^{\prime},=\mathcal{B}^{\prime},
$$

$\mathbb{C}^{\prime}=\mathscr{G}+\Delta \mathbb{C}_{Z}+\Delta \mathbb{C}_{X} \quad 、 \mathscr{G} "=\left[\begin{array}{lll}A_{1} & A_{2} & A_{3}\end{array}\right]\left\{\mathbb{b}_{\mathrm{j}}^{\mathrm{G}}\right\}$

ただし、 $\Delta B_{Z}=\delta \hat{\Theta}_{Z}\left(-\sin \Theta \cos \Phi \vec{l}_{0}+\cos \Theta \cos \Phi j_{0}\right)$ $\Delta G_{X}=\delta \hat{\Theta}_{X}\left(-\sin \Phi \not \hbar_{0}+\sin \Theta \cos \Phi k_{0}\right)$

$A_{1}=\cos \theta \cos \Phi-\sin \Theta \cos \Phi \delta \Theta-\cos \theta \sin \Phi \delta \Phi$

$A_{2}=\sin \Theta \cos \Phi+\cos \Theta \cos \Phi \delta \Theta-\sin \Theta \sin \Phi \delta \Phi$

$A_{3}=\sin \Phi+\cos \Phi \delta \Phi$

（34）式を（33）式に代入して次の関係式が導かれる。

$$
\left\{\begin{array}{l}
\delta \Theta \\
\delta \Phi
\end{array}\right\}=\left[\begin{array}{cc}
-\cos \Theta \tan \Phi & 1 \\
\sin \Theta & 0
\end{array}\right]\left\{\begin{array}{l}
\delta \hat{\Theta}_{X} \\
\delta \hat{\Theta}_{Z}
\end{array}\right\}
$$

(35)式を(32)式に代入すると、全体座標系と球座標系の等価節点モ一 メントの間の関係式が以下のように導かれる。

$$
M^{\Theta}=M_{Z} \quad M^{\Phi}=M_{X} \frac{1}{\sin \Theta}+M_{Z} \frac{\tan \Phi}{\tan \Theta}
$$

\section{5. 線形增分解析による数檤検証}

5-1. カンチレバー梁のエラスチィカ問題

計算の目的は移動座標系による幾何学的非線形性の検証と、適用 した高次平面シェル要素のメッシュ依存性を明らかにすることであ る。図 7 に示すように、5、10 および 20 個の 8 節点要素で構成 される等分割の平板モデルを用いて、板の面外および面内曲げにつ

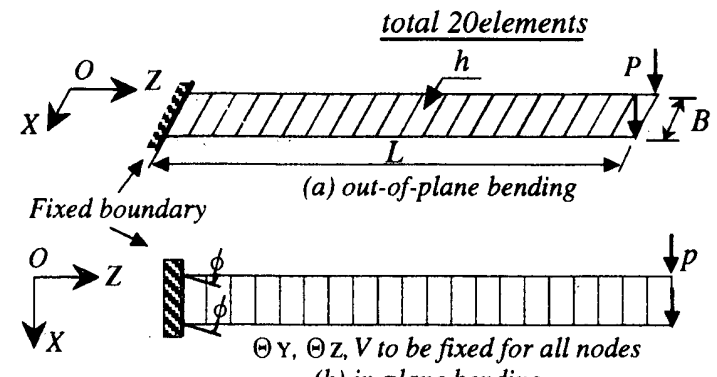
(b) in-plane bending

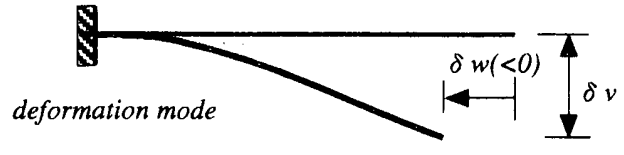

$L=100 \mathrm{~cm}, B=10 \mathrm{~cm}, h=1 \mathrm{~cm}$, $E=2100 \mathrm{t} / \mathrm{cm} 2, \nu=0.0$

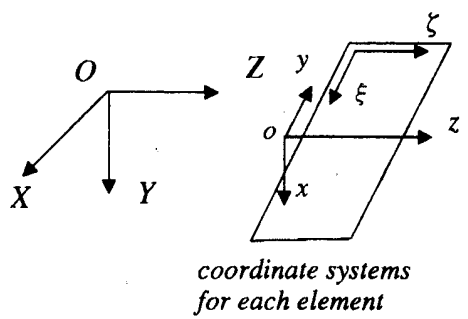

図 7：平板で構成されるカンチレバー梁
いて検討する。境界条件の中で、固定端における要素境界の面内回 転角成分 $\phi$ は許容される。また、面内曲げについては面外方向の節 点変位成分は全て拘束される。移動座標系（o-xyz）は、板要素毎に 配直する。荷重条件は、先端の 2 個の節点に撓み方向（面外ではY 軸、面内ではX軸方向）に荷重増分を一定として集中荷重を作用さ せる。解析結果は、縦軸に撛みと軸方向変位を無次元化してグラフ に整理している。増分回数は全てのケースに対して100回であ る。図中の理論解はTimoshenkoの文献を参照している ${ }^{14)}$ 。

面外曲げ挙動の解析では、要素の正味の撓みに関するVon Karman の幾何学的非線形項が、メッシュが粗い場合に厳密值よりも大きく なり、結果として図 $8 \mathrm{a}$ のように 5 要素モデルの変形が小さく抑えら れたと考えられる。ただし、5要素分割モデルであっても、綎軸が

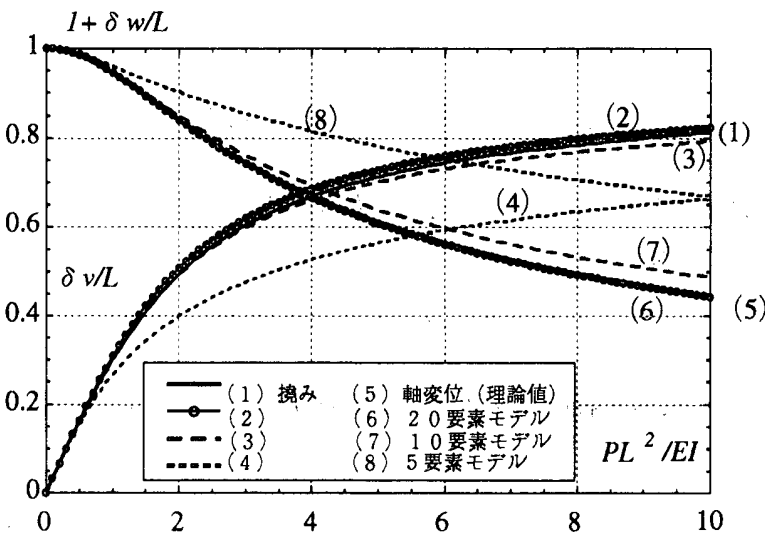

図 8a：エラスチカに関する解析結果(面外曲げ) $1+\delta w / L$

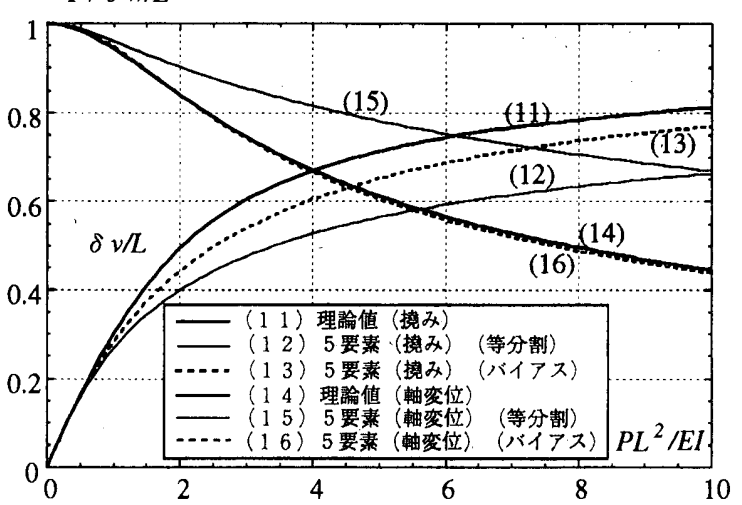

図 8 b ：エラスチカに関する解析結果(面外曲げ)

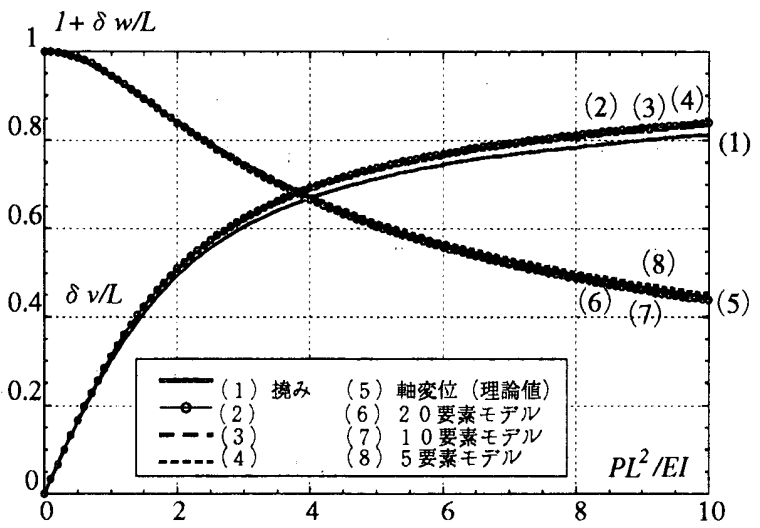

図 9： エラスチカに関する解析結果(面内曲げ) 
0.2 までは良く合っており、10 あるいは 20 要素モデルでは理論 值にほほ一致している。また、図 8 bによれば同じ 5 要素モデルで あっても、固定端に近づくにつれて要素長さを短くして撓み勾配の 与える影響を小さくしたモデル（要素長さ：5,10,20,30および $35 \mathrm{~mm}$ ）では解析精度がかなり改善されているのがわかる。した がって、要素の撓み勾配が大きくなる場合には、メッシュサイズを 小さくして、かつ移動座標系を密に配㯰することが必要である。

一方、幾何学的非線形性が移動座標によってのみ表される面内曲 げ挙動の解析では、図 9 に示すようにメッシュ依存性がみられず、 全てのケースで理論值にほぼ一致している。このことは、高性能な 高次平面シェル要素と移動座標の組み合わせが非常に効果的である ことを示している。

\section{5-2．一方向に压縮をうける周辺支持矩形平板の座屈}

計算の目的は局部座屈に関する検証である。また、局部座屈に与 える移動座標系とメッシュ分割の影響が調査される。計算対象は図

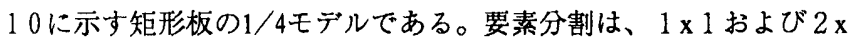
2 の 2 タイプである。また、板中央（座標系の原点）の節点の撓み 方向に板厚の $1 / 1000$ の強制変位をかけて得られた変位場を初期不 整として用いる。解析では荷重の作用する辺を強制変位させて一軸 方向の圧縮応力場を表す。合計 1000 回の増分解析結果は、図 10 に 示されている。図の縦軸は荷重值を周辺支持矩形板の座屈荷重の理 論值を用いて正規化した係数であり、横軸は板中央の撓みを示す。 図中の(1)と(3)、および (4)は、それぞれ板全体に対して1個、および 要素毎に 4 個の移動座標系を配固した場合の解析結果を表し、一方 (2)は移動座標系を使用しない場合の解析結果を表している。図より

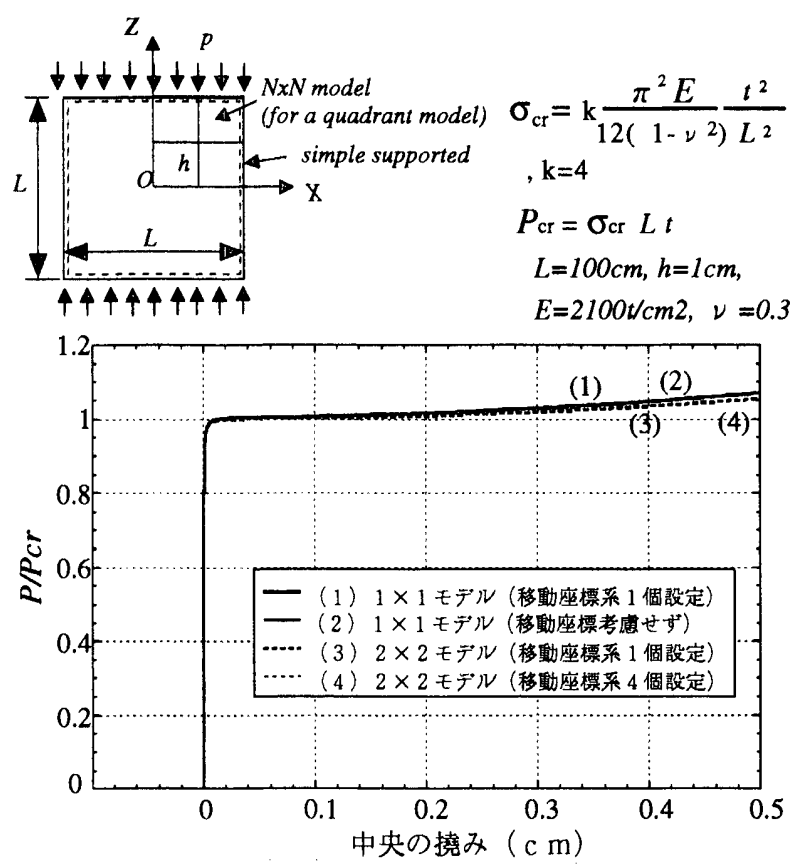

図 10 : 周辺支持矩型板の座屈解析

メッシュ分割が粗いにも拘わらず、いずれの計算結果も座屈理論值 に漸近しており良好な結果である。つまり、この例題の板の局部座 屈は移動座標系を用いない場合でも、要素の撓み勾配による歪の非 線形項によって十分な精度で計算されることがわかる。

5-3. 圧縮力をうける片持ちBOX断面柱の局部座屈を伴う曲げ座屈 計算モデルの断面寸法および解析モデルは図１１に示すように長

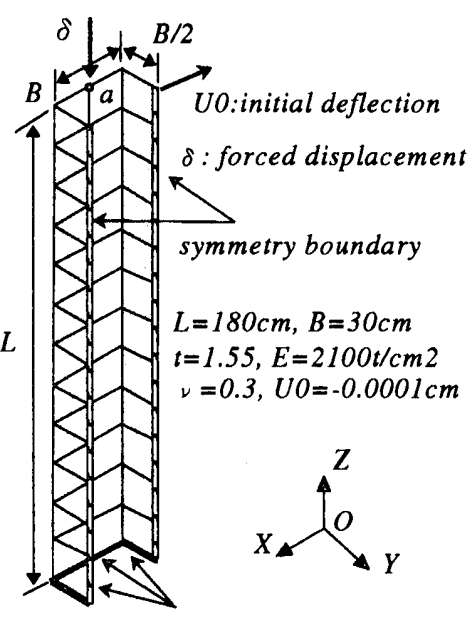

fixed boundary

but out-of-plane rotation to be free

図11：計算モデル

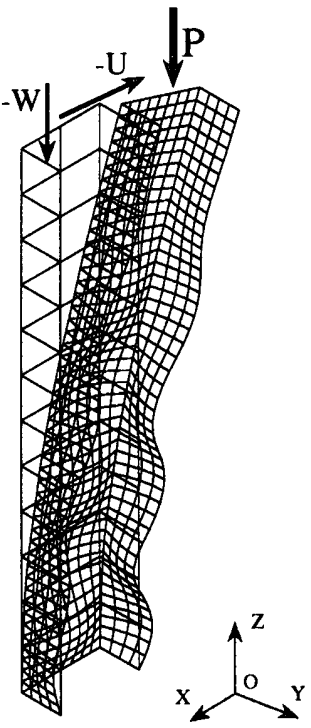

deformation mode at $\mathrm{U}=-9.65 \mathrm{~cm}$

図12：局部座屈と全体座屈の 連成モードの例

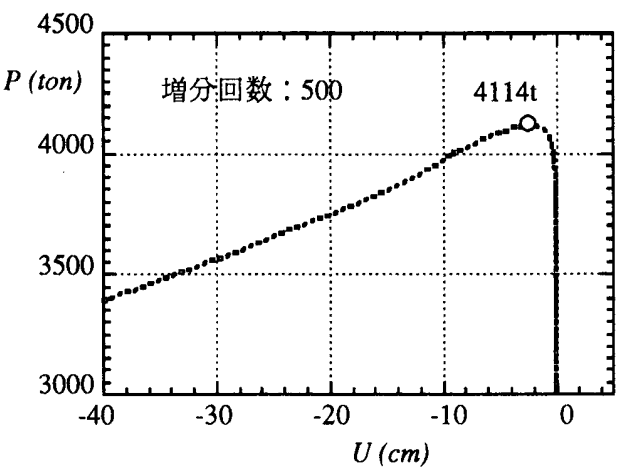

図13：軸力〜撓み関係

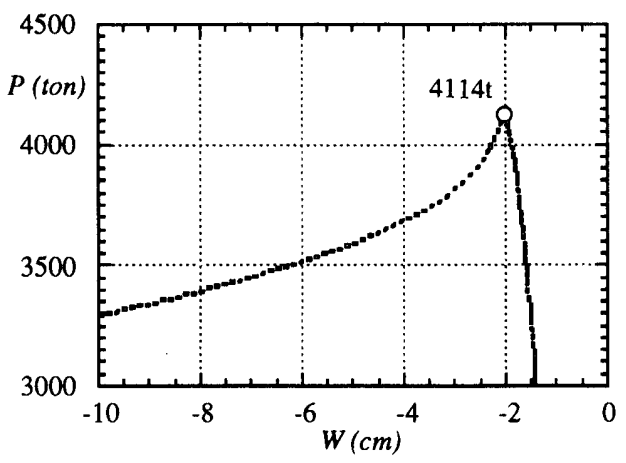

図14：軸カ〜軸方向変位関係

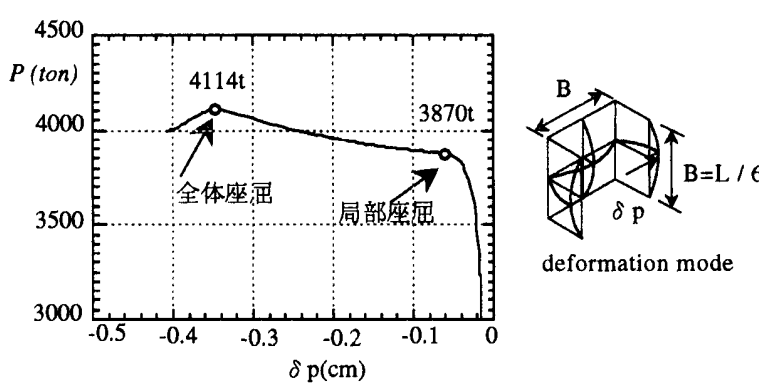

図15：パネルの面外変位の変化 
手方向 12 分割の要素数 48 の1/2対称モデルである。局部座屈を 表現できるように座屈の半波長あたり 2 分割している。また、要素 内部の変形を表示するために、1要素あたり $4 \times 4$ のサ一領域に分 割している。初期不整は、柱先端の 5 個の節点に非常に小さな 方向強制変位を与えて得られた変位場として設定している。荷重は 部材上端においてY軸回りの曲げに関する主軸位置の節点 $\mathrm{a} に て Z$ 軸の負の方向へ強制変位增分をかける。境界条件は、下端固定およ び部材上端で自由である。ただし、下端では周辺支持された平板の 面外座屈を表現するために板の面外方向回転角を自由にしている。 また、自由端では Z 軸回りの回転角を拘束して断面形状を保持して いる。板厚は $\mathrm{t}=1.55 \mathrm{~cm}$ に設定されている。この場合の柱としての オイラー座屈荷重は $4210 \mathrm{t} 、$ 板パネルの座屈荷重は37,70t (周辺支持 された矩形平板が 1 軸方向に均一に圧縮された場合を仮定して算出 した）であるため、結果としてBOXを構成する板パネルの局部座屈 が生じた後に、柱としての曲げ座屈に至ると予想される。

増分解析による結果の中で、図 12 は全体の曲げ座屈モードに局 部座屈モードが連成している様子を表している。固定端近傍では局 部座屈モードが明快に表現されているのがかかる。図 13,14 は荷 重〜変位関係を表しており、局部座屈の発生によって耐力が劣化す るのがわかる。また、その最大耐力は全体座屈の理論值4210tに比 ベて小さくなっており、局部座屈の影響で、柱の曲げ剛性が低下し たためだと考えられる。図 15 では固定端に一番近く、かつ、曲げ モーメントに関して圧縮側の板パネル中央の局部座屈の振幅を示し ている。この振幅は板の全体変位から剛体変位成分を除いた板の正 味の面外変位であるが、局部座屈、全体座屈および荷重の少化に至 る過程が十分に表現できている。

\section{6. 結論}

本論文において得た成果は以下の通りである。

(1) 平面板で構成される薄肉構造骨組を対象にして、完全適合型 長方形离次平板シェル要素の使用と、Von Karmanの大撓み理論 による要素の整み勾配による幾何学的非線形項と、要素の変形に 付随して移動する移動座標系による幾何学的非線形項を合わせ持 つ解析法を提案した。

（2）幾何剛性マトリックスは、主として全体座屈を表現する移動 座標系による非線形項成分と、主として板の局部座屈を表現する Von Karmanの歪の非線形項成分から構成されることが示され た。これらは、個別の成分として定式化されるので、単に而者を 足し合わせることで厳密に計算される。

（3）局所座標系の剛体移動を任意の 4 個の代表節点の変位成分を 用いて表現した。その上で、全体座標系と局所移動座標系の間の 節点変位成分に関する座標变換行列は、要素境界の有限回転角を 用いて厳密に定式化された。

(4)，適用した完全適合型高次平面シェル要素の要素境界の回転

は、1 辺につき 2 個の球座標系有限回転角成分によって表され る。これらの回転角成分に対する球座標系での等価節点モーメン トは、全体座標系での 3 軸回りの等価節点モーメントと厳密に関 係づけられることを示した。

（5）基本的な例題に関する解析結果と理論解を比較検証した。そ の結果、少ない要素数のモデルであっても基本的な板の局部座屈
や全体座屈が共に精度良く表わされることによって確認された。 ただし、粗いメッジュ分割のモデルを用いる場合に、剛体変位を 取り除いた要素の正味の暁みが大きくなるにつれて、撓み勾配の 2 垂項による幾何剛性が過大になる可能性を指摘した。

注 1 ）要素は 4 隅節点と 4 個の要素境界上の中間節点から構成され るKirchhoff板理論に基づく長方形平面シエル要素である。変位関 数は、曲げ変位についてはBognerの要素15) と同じ3次の撓み関 数、面内変位についても3 次関数を探用する。 4 隅の節点変位成 分は、節点の 3 方向の並進成分と、 2 本の要素境界接線べクトル の 4 個の独立な回転角成分、および掭れ率の計 8 個から成り立っ ている。中間節点の変位成分は、要素境界に沿う要素座標系変位 成分と要素境界の法線を基準にして回転する面内回転角成分から なる。また、完全適合の定義は、、要素境界上でく1>変位の連続 <2>要素境界に直交する撓み勾配の連続 <3>面内回転角が不連続 の 3 条件を常に満足することである。

注 2）要素境界接線ベクトルは単位ベクトルであり、これを用いれ ば要素境界上における適合条件を簡潔、かつ撖密に記述できる1。 注 3 ）隅節点の回転角成分は、結合する要素境界辺の 2 個の回転角 成分から構成される。N辺の要素境界が 1 個の隅節点において交 わる場合、拘束条件を課す以前の回転角成分の数は $2 \mathrm{Nである。}$

\section{参考文献}

1)上谷宏二、大神勝城:薄肉構造物解析のための高次多項式内㨉変位関数を用い た完全適合型長方形平板有限要素, 日本建等学会構造系諭文報告集第501号 ,pp.57-63, 1997.11

2) J.L.Meek and H.S.Tan :Instability analysis of thin plates and arbitrary shells using a faceted shell element with loof nodes, Computed Methods in Applied Mechanics and Engineering , Vol.57,pp.147-170,1986

3) Geir Horrigmoe and Pal G.Bergan :Nonlinear analysis of free-form shells by flat shell elements, Computed Methods in Applied Mechanics and Engineering ,Vol.16,pp.11-35,1978

4) Jian-Wu Zhang and W.B.Kratzig :Buckling analysis of rectangular plates using a four -noded finite element, Computers \& Structures, Vol.50. No.1, pp.79-86,1994

5) Kuo-Mo HSIAO :Nonlinear analysis of general shell structures by flat triangular shell element, Computers \& Structures, Vol.25 No.5, pp.665-675,1987

6) 津久一郎, 宮本 博, 山田嘉明, 山本善之: 有限要素法ハンドフック（基䃈 編），培風館，pp:37-38，1981

7）山田嘉明：有限要素法の基礎と応用シリーズ 6 塑性. 粘弾性，培風館， pp. $25-74,1980$

8) 中村恒善 : 新建築体系 36 骨組構造の解析（第 2 章），培風館, pp.199-219, 1982

9) Robert Levy, William R.Spillers :Analysis of geometrically nonlinear structures Chapman \& Hall, 1995

10) Hany Ahmed El-Ghazaly : Non-linear terms in frame analysis s using Eulerian moving co-ordinates, Commu. in Applied Nemerical Methods , Vol.7, pp.423 428,1991

11）石田修三，森迫清貴 : 増分提動法を導入した一次元複合非線形有限解析法, 日本建築学会構造系論文報告集第397号,pp.73-81, 1989.3

12）西村 督，森迫清貴，石田修三，上谷宏二 : 增分摄動法による立体骨組の大揞 み解析, 構造工学論文集 Vol.39B, pp.73-86,1993.3

13) Tetsuya Matsui and Osamu Matsuoka :A new finite element scheme for instability analysis of thin shells, International Journal for Numerical Methods in Engineering . Vol.25 No.5, pp.665-675,1987

14) ティモシェンコ,ギアー著,前沢成一郎他訳: 材料力学本論, コロナ社, pp.226$230,1975.3$

15) F.K.Bogner, R.L.Fox, and L.A.Schmit :The generation of interelement compatible stiffness and mass matrices by the use of interpolation formulae, Proc. Conf. Matrix Methods in Struct. Mech., AirForce Inst. of Tech.; Wright Patterson A.F.Base, Ohio, 1965(October)

(1997年９月19日原稿受理，1998年４月2 日採用決定） 